\title{
Problems of assessing the financial stability and security of municipalities
}

\author{
$E$ Ushakova ${ }^{1, *}, H \mathrm{Pak}^{1}$, and $A \mathrm{Kuprin}^{2}$ \\ ${ }^{1}$ Saint Petersburg University of Management Technologies and Economics, 190103, St. Petersburg, \\ Lermontovskiy Ave 44, Russia \\ ${ }^{2}$ The Russian Presidential Academy of national economy and public administration, St. Petersburg, \\ V.I., Sredniy Ave 57/43
}

\begin{abstract}
The article examines the financial stability of municipalities in conjunction with financial and budgetary security. The analytical base is provided by the information of the Federal State Statistics Service, the section Municipal Statistics, the database of the Leningrad Oblast. The article proposes methodological approaches to the assessment of financial stability and security of municipalities that can be used by authorities at all levels for monitoring studies of the sustainable and safe development of municipalities. The assessment of financial stability and financial and budgetary security will offer a more representative measure of the effectiveness of municipal management.
\end{abstract}

\section{Introduction}

The relevance of the study is due to the need to determine the financial stability and security of municipalities. At present, there are practically no works devoted to a comprehensive study of the financial stability and security of municipalities. Most existing studies consider only some aspects of the problem, for example, separate uncorrelated indicators, which do not reflect the features and priorities of the municipalities development.

The problem of assessing the financial stability and security of municipalities is still virtually unexplored, since its solution requires clarification of the methodological and theoretical provisions for evaluating these categories at the municipal level.

The country's stability and security is ensured by the stability and security of the socioeconomic systems of a lower management level, for example, regional, municipal, etc., that is, the security of systems of all levels, each of them corresponding to a certain system of security elements. Security is the main dominant idea of the sustainable development. Categories of stability and security are non-separable.

The system of indicators of financial stability and security of the municipality, which includes such indicators as debt ratio, leverage ratio, the solvency ratio, accounts receivable and accounts payable, own budget revenues per capita, fiscal capacity, budget debt-service burden, etc., corresponds to the indicators used in assessing the financial stability and security at the level of the region or the enterprise [1]. While the problem to solve is well-

\footnotetext{
* Corresponding author: natali-pak@yandex.ru
} 
developed at the level of the country and the region, it remains almost unexamined at the municipal level.

The purpose of the study is to determine the financial stability and financial and budgetary security of the municipality development.

\section{Methods}

There are the following methodological approaches to determine the financial stability and safety of the development of a municipality [2-3]:

1. Use of certain indicators, for example, the growth rate of budget revenues, the ratio of the volume of borrowings to budget revenues, the share of expenses for servicing municipal debt in the total amount of budget expenditures, the proportion of unprofitable enterprises, etc.;

2. Use of integral criteria of the financial stability of the region due to the absence of wellresearched and approved methodological approaches to assessing the financial stability of the municipality development, financial stability being determined by:

$$
\mathrm{FS}=0.75^{*} \mathrm{OR} / \operatorname{Exp}+0.15 *[1-(\mathrm{APe}-\mathrm{ARe} / \mathrm{APb}-\mathrm{ARb})]+0.1 *(1-\mathrm{Ue} / \mathrm{Ub})
$$

Where: OR is own budget revenues;

Exp is budget expenditures;

$\mathrm{APb}, \mathrm{APe}, \mathrm{ARb}, \mathrm{ARe}$ are overdue accounts payable and accounts receivable at the beginning and at the end of the year;

$\mathrm{Ub}$, Ue are the proportions of unprofitable enterprises in the total number of enterprises at the beginning and at the end of the year.

Financial stability within certain limits is characterized by the following factors [4-5]:

- absolutely stable, if FS $=0.1-1$;

- relatively stable, if $\mathrm{FS}=0.7-0.8$;

- depressive, if FS $=0.5-0.5$;

- $\quad$ pre-crisis, if FS $=0.2-0.5$;

- $\quad$ crisis, if FS $\leq 0.2$.

Next, we consider the system of financial and budgetary security indicators of municipalities, which is most typical of the municipalities of the Leningrad Oblast and differs from the existing ones. These indicators are represented in Table 1.

Table 1. Brief description of financial and budgetary security indicators of municipalities.

\begin{tabular}{|l|l|l|l|}
\hline Indicators & Formula & Threshold values & Meaning \\
\hline $\begin{array}{l}\text { Budget balance in- } \\
\text { dicator (BB) }\end{array}$ & $\begin{array}{l}\mathrm{BB}=\mathrm{R} / \mathrm{Exp}, \\
\text { where R is budget } \\
\text { revenues; } \\
\text { Exp is budget expend- } \\
\text { itures. }\end{array}$ & $\begin{array}{l}\mathrm{BB} \geq 1 \text { lated of } \\
\text { Budgetary Code of the } \\
\text { Russian Federation, } \\
\text { Article 92, paragraph } \\
2\end{array}$ & $\begin{array}{l}\text { Indicates the level } \\
\text { budgetary balance } \\
\text { without borrowing }\end{array}$ \\
\hline Budget deficit (BD) & $\mathrm{BD}=\mathrm{R}$ - Exp & $\begin{array}{l}\mathrm{BD} \leq 10 \% \text { of budget } \\
\text { revenues } \\
\text { Budgetary Code of the } \\
\text { Russian Federation, } \\
\text { Article 92, paragraph } \\
5\end{array}$ & $\begin{array}{l}\text { Indicates the excess of } \\
\text { budget expenditures } \\
\text { over its revenues }\end{array}$ \\
\hline Leverage ratio (LR) & $\begin{array}{l}\mathrm{LR}=\mathrm{OR} / \mathrm{R}, \text { where } \\
\text { OR is own budget } \\
\text { revenues }\end{array}$ & $\begin{array}{l}\text { The proportion of } \\
\text { own incomes shows a } \\
\text { level of provision of a } \\
\text { municipality with } \\
\text { own resources for }\end{array}$ \\
\hline
\end{tabular}




\begin{tabular}{|l|l|l|l|}
\hline & & & $\begin{array}{l}\text { dealing with the local } \\
\text { issues }\end{array}$ \\
\hline $\begin{array}{l}\text { Fiscal capacity of } \\
\text { the municipality per } \\
\text { capita (FCm) }\end{array}$ & $\begin{array}{l}\mathrm{FCm}=\mathrm{Exp} / \mathrm{N} \text {, where } \\
\mathrm{N} \text { is population of the } \\
\text { municipality }\end{array}$ & $\begin{array}{l}\mathrm{FCm} \geq \text { average } \mathrm{FCm} \\
\text { over the territory }\end{array}$ & $\begin{array}{l}\text { Indicates the level of } \\
\text { the budget expendi- } \\
\text { tures per capita }\end{array}$ \\
\hline $\begin{array}{l}\text { Ratio of accounts } \\
\text { receivable and pay- } \\
\text { able (Rarp) }\end{array}$ & $\begin{array}{l}\text { Rarp }=\mathrm{AR} / \mathrm{AP} \text {, where } \\
\text { AR and AP are over- } \\
\text { due accounts receiva- } \\
\text { ble and accounts pay- } \\
\text { able of the municipali- } \\
\text { ty }\end{array}$ & $\begin{array}{l}\text { Indicates the efficien- } \\
\text { cy of using own and } \\
\text { borrowed financial } \\
\text { resources }\end{array}$ \\
\hline $\begin{array}{l}\text { The proportion of } \\
\text { unprofitable enter- } \\
\text { prises in the total } \\
\text { number of enter- } \\
\text { prises (U) }\end{array}$ & $\begin{array}{l}\mathrm{U}=\mathrm{Nu} \text { /Nt, where Nu } \\
\text { and Nt are the number } \\
\text { of unprofitable enter- } \\
\text { prises and the total } \\
\text { number of enterprises }\end{array}$ & $\begin{array}{l}\text { minimal U } \\
\text { over the territory }\end{array}$ & $\begin{array}{l}\text { Indicates the work } \\
\text { efficiency of the en- } \\
\text { terprises located on } \\
\text { the municipality terri- } \\
\text { tory }\end{array}$ \\
\hline
\end{tabular}

Source: the table was compiled by the authors.

In this table, we considered the methodology for determining these indicators, their threshold values and their meaning.

\section{Results}

The calculation results for the proposed methods are presented in Tables 2 and 3.

Table 2. Financial stability of the municipal districts of the Leningrad Oblast for 2016.

\begin{tabular}{|c|c|c|c|}
\hline Municipal districts & $\begin{array}{l}\text { Financial stability } \\
\text { indexes of the munici- } \\
\text { palities } \\
\text { (FS) }\end{array}$ & $\begin{array}{l}\text { Stability level of the } \\
\text { municipalities }\end{array}$ & $\begin{array}{l}\text { Stability bounda- } \\
\text { ries }\end{array}$ \\
\hline Volosovsky & 0.617 & \multirow[t]{3}{*}{ Depressive } & \multirow[t]{3}{*}{$\mathrm{FS} \geq 0.5-0.7$} \\
\hline Slantsevsky & 0.544 & & \\
\hline $\begin{array}{l}\text { Sosnovoborsky } \\
\text { urban okrug }\end{array}$ & 0.548 & & \\
\hline Volkhovsky & 0.395 & \multirow[t]{8}{*}{ Pre-crisis } & \multirow[t]{8}{*}{$\mathrm{FS} \leq 0.5$} \\
\hline Vsevolozhsky & 0.216 & & \\
\hline Gatchinsky & 0.320 & & \\
\hline Kirishsky & 0.299 & & \\
\hline Luzhsky & 0.319 & & \\
\hline Priozersky & 0.470 & & \\
\hline Tikhvinsky & 0.381 & & \\
\hline Tosnensky & 0.428 & & \\
\hline Vyborgsky & 0.111 & \multirow[t]{4}{*}{ Crisis } & \multirow[t]{4}{*}{$\mathrm{FS} \leq 0.2$} \\
\hline Kingiseppsky & -0.324 & & \\
\hline Boksitogorskiy & -0.007 & & \\
\hline Kirovsky & -1.633 & & \\
\hline
\end{tabular}

Source: the table was compiled by the authors on the basis of the statistical data "The municipal districts and the urban okrug of the Leningrad Oblast, 2016" [6-9]. 
The table evidences that most of the municipal districts of the Leningrad Oblast are in a pre-crisis state. Financial stability of the Lodeinopolskiy and Podporozhsky municipal districts was not determined due to lack of data. Financial stability indexes of three municipalities exceed those of the others, but they indicate a depressive state of these municipalities. There is no municipality in the oblast which would possess absolute or relative financial stability. Vyborgsky, Kingiseppsky, Boksitogorskiy and Kirovsky municipal districts of the Leningrad Oblast are in a crisis state.

Table 3. Indicators of budgetary and financial security of municipal districts of the Leningrad Oblast for 2016.

\begin{tabular}{|c|c|c|c|c|c|c|}
\hline & 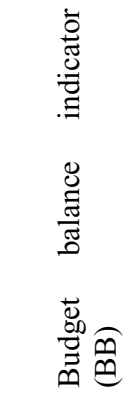 & 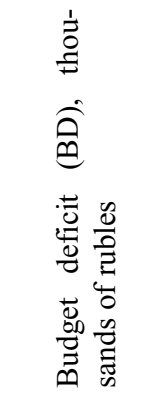 & 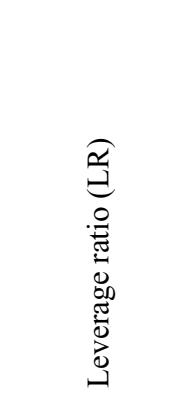 & 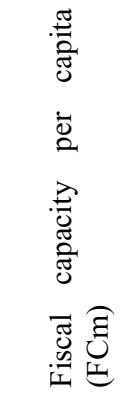 & 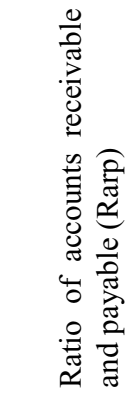 & 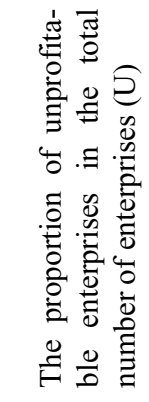 \\
\hline $\begin{array}{l}\text { Threshold val- } \\
\text { ues }\end{array}$ & $\mathrm{BB} \geq 1$ & $\begin{array}{l}\mathrm{BD} \leq 10 \% \\
\text { of budget } \\
\text { revenues }\end{array}$ & $0,5<\mathrm{LR}<0,7$ & $\begin{array}{l}\mathrm{FCm} \geq \\
\text { average } \\
\mathrm{FCm} \\
\text { over the } \\
\text { oblast } \\
(30.05)\end{array}$ & $\operatorname{Rarp} \geq 1$ & $\mathrm{U}=11.11$ \\
\hline $\begin{array}{l}\text { municipal dis- } \\
\text { tricts: }\end{array}$ & & & & & & \\
\hline Boksitogorskiy & 0.976 & -33349 & 0.444 & 27.6 & 0.324 & 26.32 \\
\hline Volosovsky & 1.040 & 73802 & 0.601 & 35.3 & 27.500 & 11.76 \\
\hline Volkhovsky & 1.041 & 93901.6 & 0.434 & 25.1 & 0.361 & 66.67 \\
\hline Vsevolozhsky & 1.006 & 47538 & 0.654 & 27.8 & 3.302 & 33.33 \\
\hline Vyborgsky & 1.031 & 145208 & 0.473 & 23.0 & 1.378 & 25 \\
\hline Gatchinsky & 1.040 & 200757.6 & 0.442 & 20.3 & 1.980 & 28.57 \\
\hline Kingiseppsky & 1.124 & 242080.7 & 0.519 & 24.7 & 0.213 & 16.67 \\
\hline Kirishsky & 0.991 & -18551 & 0.521 & 31.1 & 0.686 & 50 \\
\hline Kirovsky & 0.954 & -110057.6 & 0.448 & 22.7 & 1.932 & 50 \\
\hline Lodeinopolskiy & 1.012 & 12373 & 0.508 & 34.4 & & 66.67 \\
\hline Lomonosovsky & 0.999 & -1744 & 0.625 & 31.5 & & 14.29 \\
\hline Luzhsky & 1.027 & 53222 & 0.476 & 26.4 & 0.570 & 66.7 \\
\hline
\end{tabular}




\begin{tabular}{|l|l|l|l|l|l|l|}
\hline Podporozhsky & 1.054 & 64902 & 0.586 & 40.0 & & 33.33 \\
\hline Priozersky & 0.996 & -6835 & 0.508 & 28.2 & 3.150 & 14.29 \\
\hline Slantsevsky & 0.974 & -34655.7 & 0.510 & 31.0 & 2.563 & 28.57 \\
\hline Tikhvinsky & 1.019 & 37550 & 0.452 & 28.5 & 1.004 & 25 \\
\hline Tosnensky & 1.001 & 3249 & 0.494 & 19.7 & 2.383 & 25.86 \\
\hline $\begin{array}{l}\text { Sosnovoborsky } \\
\text { urban okrug }\end{array}$ & 0.965 & -80780 & 0.638 & 33.7 & 1.581 & 11.11 \\
\hline
\end{tabular}

Source: the table was compiled by the authors on the basis of the statistical data "The municipal districts and the urban okrug of the Leningrad Oblast, 2016".

Depressive municipal districts of the Leningrad Oblast are characterized by high values of budget balance. All budgets were implemented with a surplus apart from Boksitogorskiy, Kirishsky, Kirovsky, Lomonosovsky, Priozersky and Slantsevsky districts. Own revenues amount to a little more than $50 \%$ of the total revenues. This means that a significant portion of the budget is represented by the budget transfers from the upper levels of the budget system. The fiscal capacity per capita of Volosovsky district exceeds the average regional value by 5.3 thousand rubles. The ratio of accounts receivable and payable in these municipalities corresponds to the threshold value, which reflects the effective use of own and borrowed funds. The proportion of unprofitable enterprises in the total number of enterprises corresponds to the threshold value only in the Sosnovoborsky urban okrug.

Crisis districts, despite the balanced budget (Vyborgsky, Kingiseppsky districts), significantly depend on transfers from the budgets of the upper levels of the budget system. Fiscal capacity per capita of these districts is less than the average over the oblast; for example, FCm of the Vyborgsky district is 23 thousand rubles (average FCm over the oblast is 30.05). Ratio of accounts receivable and payable in the Boksitogorsky and Kingiseppsky municipal districts is much lower than the threshold value. This indicates a low efficiency of using own and borrowed financial resources. A significant proportion of unprofitable organizations is observed, for example, in the Kirovsky district it amounts to $50 \%$. It should be noted that even though most of the security indicators exceed the established threshold, this means not a malfunction of the municipality, but a need for the intervention of regulatory and administrative authorities in order to prevent the emerging threats.

\section{Discussion}

The novelty of the study lies in the fact that in the context of the undeveloped problem of assessing the financial stability and security of municipalities, presented system of indicators for assessing financial and budgetary security, in our opinion, represents a set of linked indicators and reflects the features and priorities of the development of the municipalities of the Leningrad Oblast.

Then, using an integrated assessment of the financial stability of the region due to the lack of such techniques for municipalities, we received an illustrative practical tool for assessing the financial stability of municipalities. Assessing the financial and budgetary security of municipalities, in our opinion, requires not only developing a system of indicators for assessing this security, but also assessing the financial stability of 
municipalities. Categories of stability and security of the territory development are nonseparable.

\section{Conclusions}

1. Monitoring researches of regulatory and administrative authorities at the municipal level must necessarily include indicators and thresholds for the security of the development of the territory, which identify factors that destabilize the social and economic development of municipalities and deny the principles of sustainable development.

2. It should be noted that most of the existing systems of indicators of assessing financial and budgetary security are not entirely interlinked and do not reflect the features and priorities of the development of municipalities.

3. Security is the main dominant idea of the sustainable development of the territory. Based on this, when assessing security, it is important not only to develop a system of indicators for assessing this security, but also to assess the financial stability of municipalities.

4. This approach to assess the financial stability and security of the municipality can be used by the executive and administrative authorities when forecasting the financial condition of the territory and determining the quality of financial management of municipalities.

\section{References}

1. C.T. Edmonds, J.E. Edmonds, B.Y. Vermeer, T.E. Vermeer, Journal of Accounting and Public Policy 36(2), 163-176 (2017)

2. C. Foltin, Research in Accounting Regulation 29(1), 19-29 (2017)

3. M.S. Senatro, D. Leoa, C. Nakos, H. Maras, S. Panevski, O. Fülöp, S. Papagianni, Z. Tarevska, D. Čeh, E., Szabó, B. Bodzsár, Renewable and Sustainable Energy Review 50, 480-496 (2015)

4. N.E. Zhigalova, UMK, VVAGS, 35-36 (2008)

5. S. Cohena, M. IDoumpos, E. Neofytou, C. Zopounidis, European Journal of Operational Research 218(1), 270-279 (2012)

6. The municipal districts and the urban okrug of the Leningrad Oblast, Statistical bulletin. Petrostat (2016)

7. Economics of the municipal districts and the urban okrug of the Leningrad Oblast Statistical handbook (Petrostat, 2015)

8. URL : http://lenoblinvest.ru

9. URL: http://econ.lenobl.ru 